\title{
Acute hepatic porphyria: when to perform liver transplantation?
}

\author{
Porfiria hepática aguda: quando realizar o transplante hepático?
}

Maria Eugênia Carinhani de Cico $^{1}$ (D), Amanda Macedo Sanches Mateus ${ }^{1}$ (D), Bruna Forte Giacheto (D) $^{\text {, Zumira }}$ Aparecida Carneiro $^{1}$ (D), Charles Marques Lourenço ${ }^{1,2}$ (i)

\begin{abstract}
Acute hepatic porphyrias (AHPs) are inborn errors of hemebiosynthesis and its most common and severe type is the acute intermittent porphyria (AIP). AIP is an hereditary autosomal dominant disease caused by accumulated porphobilinogen deaminase (PBG) and delta aminolevulin acid (ALA) products. The main symptoms are severe abdominal pain, neuromuscular and psychiatric disturbances, nausea, vomiting, encephalopathy, tachycardia, seizures, tremors and hypertension, that usually are manifested by acute crises. The treatment is based on clinical management and in cases which the patient's quality of life is affected liver transplantation (LT) may be an alternative choice. We report the case of a patient with AHP presenting recurrent crisis leading to chronic symptoms occurrence and poor quality of life with progressive unresponsiveness to hemin treatment. Patient was submitted to LT as curative therapy proposal, but patient still presents some clinical manifestations that may indicate the possibility of a secondary cause to explain persistence of her symptoms despite of biochemical normalization of ALA and PBG.
\end{abstract}

Keywords: Acute intermittent porphyria, Porphyria, Liver transplantation, Porphobilinogen deaminase.

\section{RESUMO}

As porfirias hepáticas agudas (PHA) compreendem um grupo de porfirias que apresentam erros inatos na biossíntese do grupo heme, sendo a mais severa e o tipo mais comum da PHA, a porfiria aguda intermitente (PAI). A PAI é uma doença autossômica dominante causada pelo acúmulo dos produtos porfobilinogênio deaminase (PBG) e ácido delta-aminolevulínico (ALA). Os principais sintomas são dor abdominal intensa, distúrbios neuromusculares e psiquiátricos, náuseas, vômitos, encefalopatia, taquicardia, febre, tremores e hipertensão, os quais normalmente são manifestados durante as crises agudas. O tratamento é baseado no manejo clínico de todos pacientes durante a crise. Para os casos em que a qualidade de vida do paciente é afetada negativamente, a terapêutica de transplante hepático poderá ser indicada. O objetivo do relato de caso é introduzir o tratamento de uma paciente com recorrentes crises agudas de porfiria e danos em sua qualidade de vida. Uma vez que a paciente não apresentou melhora após tratamento com hematina, foi submetida ao transplante hepático visando a cura da doença. Após o transplante, a paciente ainda apresentou alguns sintomas clínicos, necessitando reformular uma segunda hipótese para explicar a persistência de tais sintomas apesar da normalização dos níveis de ALA e PBG.

Palavras-chave: Porfiria intermitente aguda, Porfiria, Transplante hepático, Porfobilinogênio deaminase..

1. Faculdade de Medicina. Centro Universitário Estácio de Ribeirão Preto, (SP), Brasil

2. Centro Paulista de Diagnóstico, Pesquisa e Treinamento, Ribeirão Preto, (SP), Brasil 


\section{INTRODUCTION}

There are different types of porphyria but acute intermittent porphyria (AIP) is the commonest and most severe one, that is caused by an inherited deficiency of porphobilinogen deaminase (PBG). ${ }^{1-3}$ The autosomal-dominant disorder can be diagnosed by clinical symptoms, PBG and delta-aminolevulinic-acid (ALA) urinary levels. Afterwards, other tests might be included for genetic mutation identification. ${ }^{4,5}$

Figure 1 Heme group synthesis.

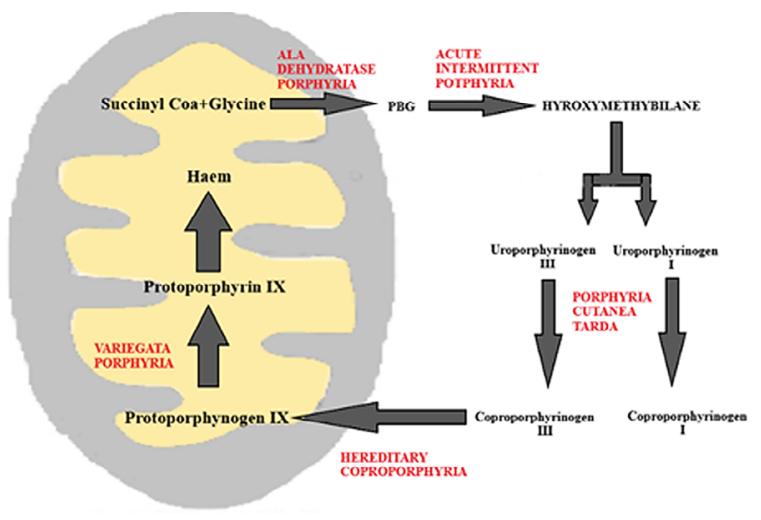

Font: The authors.

Generally, AHP comprise recurrent acute attacks usually characterized by severe abdominal pain, dysautonomic features, neuromuscular, psychiatric disturbances, nausea, vomiting, constipation and diarrhea. Cardiovascular signs may occur, like tachycardia, hypertension and hyponatremia. ${ }^{1,2,5-8}$

Treatment is based in control of pain, management of seizures, dextrose administration and correction of electrolyte imbalances. ${ }^{1,9}$ Current approved treatment for the acute attacks is administration of intravenous hemin infusions and/or gonadotropin releasing hormone analogs. ${ }^{11}$

Nevertheless, recurrent attacks may result in chronic symptoms causing major impairment in patients quality of life..$^{1,2}$ Liver transplantation (LT) is indicated according to responsiveness to pharmacological treatment, frequency and severity of the attacks and patient's quality of life.

\section{CASE REPORT}

A 16-year-old female had localized severe acute abdominal pain, mainly at epigastric and periumbilical region with profuse vomiting. Medical history showed repeated hospital admissions where she had been investigated for celiac disease and treated with oral analgesics but her clinical condition still remained unchanged. During admissions, she progressed with autonomic symptoms, vomiting, acute abdominal pain, convulsions, symmetrical motor weakness and a burning sensation in both arms and legs.

Her first episodes of severe acute abdominal pain began when she was 12 years old, during her menarche, with episodes usually starting 10 days before her menstrual period and frequently persisted the entire menstrual cycle. Each pain episode was accompanied by reddish-colored urine excretion, nausea, constipation and she also referred confusion with some erratic behavior.

Her clinical history showed that she suffered anxiety, depression, and migraine. There was no history of excessive alcohol drinking, smoking, illicit drug usage, or food poisoning. Family history showed that her mother started, also in menarche, with similar symptoms like abdominal pain, constipation with intermittent diarrhea, migraine, and fever.

Physical abdominal examination only revealed flat abdomen with mild tenderness on deep palpation mainly in the epigastric and periumbilical regions..

During acute episodes, she showed hiponatremia with other electrolytes, glucose, urea, and creatinine within the reference values. No abnormalities were observed in blood count, urine culture or in liver function. Endoscopy with histopathological analysis, opaque enema, colonoscopy, pelvic MRI, total abdominal computed tomography, and videolaparoscopy didn't show any abnormal findings. The suspicion of celiac disease was ruled out.

Suspicion of acute porphyria was raised and later confirmed Erlich urine test was positive and quantitative urine PBG levels were increased in 2 acute attacks ( 5.51 and $31.5 \mathrm{mg} / 24$ hours, reference range: less than $2.4 \mathrm{mg} / 24 \mathrm{~h}$ ). Nevertheless, ALA measurement in different occasions was always below the reference range.

Initially, she was successfully treated with intravenous infusion of glucose and hemin therapy. Pain and nausea were controlled with morphine, tenoxicam, ondansetron, and paracetamol. Within a few days, the acute abdominal pain and other symptoms resolved and the patient show clinical recovery. However, patient experienced monthly 
episodes of acute crises that only seemed to respond to hemin therapy. Modulation of menstrual cycle was tried without success.

She was unable to work or complete her college education because of continuous symptoms. Patient became increasingly disabled and depressed with chronic abdominal, back and lower-extremity pain that required continued high doses of opioid analgesics. Since patient's symptoms showed progressively refractory to hemin, the infusions were performed weekly but her symptoms rapidly come back. After months of multiple hospitalizations, LT was considered and occurred when she was 20 years old.

After LT, patient referred improvement in seizures control, but still complaints of recurrent abdominal pain, migraine and intermittent diarrhea. She tolerated well LT, however developed diabetes needing insulin therapy. New ALA and PBG urine levels were unremarkable.

Presently she is in oral immunosuppression and pain management with opioids and also has been using gabapentin for seizures control. Even though her ALA and PBG levels remain controlled, patient still shows recurrent abdominal pain attacks that sometimes require hospitalization.

\section{DISCUSSION}

AHP are inborn errors of metabolism, caused by a disturbance in the heme biosynthesis pathway, resulting in high ALA and PBG urine levels. Consequently, patients usually have abdominal pain, peripheral neuropathy and psychiatric disturbances. Symptoms normally comes as acute attacks triggered by drugs, chemicals, alcohol intake and smoking.

Neurovisceral symptoms are often common in women after puberty by second and third decades of life, decreasing after menopause. This reflects the influence of female sex hormones and cyclic attacks during menstrual cycles. ${ }^{1,6,7}$

Treatment for acute attacks is based discovering which factor was a trigger for the patient, Hemin intravenous administration therapy and palliative care with narcotic analgesics, antiemetics and correction of electrolyte imbalances. ${ }^{9}$ Gonadotropin (GnRh) infusion can be used to prevent ovulation and avoid recurrent attacks related to menses. ${ }^{1,9}$ Our patient started with GnRh analogs because it was not achieved a satisfactory control of the cyclic attacks and hemin therapy was used weekly when she started showing progressively symptoms, but then, due to economic restraints, this medication was suspended.

In fact, recurrent attacks are often difficult to control and can result in chronic symptoms with constant hospitalizations that severely impair quality of life, ${ }^{10}$ as occurred with our patient who experienced monthly episodes of acute attacks and was unable to work or complete college education. When acute attacks are life-threatening and incapacitating, such as our patient case, LT can be considered as a curative treatment in addition to prevent for neurological damage. As reported, LT was considered due to the marked impairment of quality of life, coupled with the rapid relapse of symptoms after hemin infusions. ${ }^{11}$

After LT patients usually have remarkable improvement in a short period of time and the urinary levels of ALA and PBG rapidly normalized. ${ }^{12}$ Despite of the success of the $L T$, our patient did not show a clinical improvement since she still complained about abdominal pain, although her ALA and PBG levels became normal. It is important to consider that her new pain "attacks" after LT could be related not to AHP but to opioid addiction, a clinical complication that is not uncommon in AHP patients. ${ }^{13}$

Since LT is a complex procedure and require use of immunosuppression along patient life, it should be proposed as a last resource treatment, in particular because there are new therapeutic approaches being developed, such as RNA modulation and gene therapies. ${ }^{14}$

The specific drug that has shown good effect in studies is Givosiran, a drug that may be used on recurrent acute attacks and offers a second option for hemin infusion, being an new alternative for non realization of LT. Medication has been selectively taken up by hepatocytes and has led to marked and sustained decrements in urinary ALA and PBG levels and to clinically meaningful decreases in frequency and severity of acute attacks, hospitalizations and intravenous heme therapy. ${ }^{7,10,15}$

\section{REFERENCES}

1. Yasuda M, Erwin AL, Liu LU, Balwani M, Chen B, Kadirvel $S$, et al. Liver transplantation for acute intermittent porphyria: biochemical and pathologic studies of the explanted liver. Mol Med. 2015; 2(1):487-95. 
2. Malinzak EB, Knudsen NW, Udani AD, Vikraman D, Sudan DL, Miller TE. Perioperative Challenges in Liver Transplantation for a Patient With Acute Intermittent Porphyria. J Cardiothorac Vasc Anesth. 2018; 32(6) 2716-20.

3. Stojeba N, Meyer C, Jeanpierre C, Perrot F, Hirth C, Pottecher T. Recovery from a variegate porphyria by a liver transplantation. Liver Transpl. 2004; 10(7)935-8.

4. Frei $P$, Minder EI, Corti N, Muellhaupt B, Geier A, Adams $H$, et al. Liver transplantation because of acute liver failure due to heme arginate overdose in a patient with acute intermittent porphyria. Case Rep Gastroenterol. 2012; 6(1) 190-6.

5. Anderson, K, Bloomer, J R, Bonkovsky, H L., Kushner, J P., Pierach, C A, Pimstone, N R. Erratum: Recommendations for the diagnosis and treatment of the acute porphyrias Ann of Intern Med (2005) 142 (439-450). Ann of Intern Med. 2005; 143(4) 316.

6. Warholm C, Wilczek H. Renal transplantation in a case of acute intermittent porphyria. J Clin Pharmacol. 2003; 43(10)1158-60.

7. Singal AK, Parker C, Bowden C, Thapar M, Liu L, McGuire BM. Liver transplantation in the management of porphyria. Hepatology. 2014; 60(3)1082-89.

8. Turton-Weeks S, Barone GW, Gurley BJ, Ketel BL, Lightfoot ML, Abul-Ezz SR, et al. Pretransplant evaluation of a patient with acute intermittent porphyria. Prog Transplant. 2001; 11(3) 214.
9. Soonawalla ZF, Orug T, Badminton MN, Elder GH, Rhodes JM, Bramhall SR, Elias E. Liver transplantation as a cure for acute intermittent porphyria. Lancet. 2004; 363(9410)705-6.

10. Dar FS, Asai K, Haque AR, Cherian T, Rela M, Heaton N. Liver transplantation for acute intermittent porphyria: a viable treatment? Hepatobiliary Pancreat Dis Int. 2010;9(1):93-6.

11. Schmitt, C, Lenglet, $H$, Yu, A, Delaby, C, Benecke, A, Lefebvre, $T$, et al. Recurrent attacks of acute hepatic porphyria: major role of the chronic inflammatory response in the liver. J Intern Med. 2018; 284(1) 78-91.

12. Al-Samkari, H, Patel, A A., Schiano, T D., \& Kuter, D J. Recurrence of Acute Intermittent Porphyria After Liver Transplantation. Ann Intern Med. 2019; 170 (12) 904-905.

13. Cardenas, J L., \& Guerrero, C. Acute intermittent porphyria: general aspects with focus on pain. Current medical research and opinion. 2018; $34 \mathrm{~J}$ Hepatol.(7), 1309-1315.

14. Fontanellas, A, Ávila, M A., Anderson, K E., \& Deybach, J C. Current and innovative emerging therapies for porphyrias with hepatic involvement. J Hepatol. 2019;71(2):422-33.

15. Wang B, Rudnick S, Cengia B, Bonkovsky HL. Acute Hepatic Porphyrias: Review and Recent Progress. Hepatol Commun. 2018 20;3(2):193-206. 
Todos os autores participaram da concepção do trabalho com contribuições substanciais para a concepção e design, aquisição de dados, análise e interpretação dos dados e redação do artigo, com aprovação final da versão a ser publicada, obedecendo, portanto, aos requisitos uniformes do Comitê Internacional de Editores de Periódicos Médicos.

Os autores autorizam a transferência de direitos autorais, no qual reconhecem que, a partir da submissão, o periódico Revista Medicina passa a ser detentor dos direitos autorais do manuscrito.

Não há conflitos de interesse em potencial que possam influenciar o processo de publicação, e que não há ligação de qualquer um dos autores com empresas e/ou companhias que possam ter qualquer interesse na divulgação do manuscrito submetido à publicação.

Foram respeitados os princípios éticos de pesquisa com seres humanos, em conformidade com a Resolução ${ }^{\circ}{ }^{\circ}$ 466/2012, Resolução $n^{\circ}$ 510/2016 e que o mesmo obteve aprovação pelo Comitê de Ética em Pesquisa da nossa instituição, sob parecer de número 2.190.929 na data de 28 de julho de 2017 sob o seguinte número do CAAE 70623317.7.0000.5581 gerado pela Plataforma Brasil.

Não houve agência de apoio ou financiamento que tenham contribuído para o desenvolvimento desse trabalho, o mesmo partiu da concepção dos autores em face da necessidade de relatar na literatura médica os aspectos clínicos do caso a fim de auxiliar outros médicos quando enfrentarem situações clínicas semelhantes em paciente acometido dessa rara doença genética.

Corresponding Author:

Charles Marques Lourenço

charlesgenetica@gmail.com / charles.lourenco@estacio.br

Editor:

Prof. Dr. Felipe Villela Gomes

Received in: nov 20, 2020

Approved in: apr 09, 2021 